\title{
Glaciecola arctica sp. nov., isolated from Arctic marine sediment
}

\author{
Yan-Jiao Zhang, ${ }^{1}$ Xi-Ying Zhang, ${ }^{1}$ Zi-Hao Mi, ${ }^{1}$ Chun-Xiao Chen, ${ }^{1}$ \\ Zhao-Ming Gao, ${ }^{1}$ Xiu-Lan Chen, ${ }^{1}$ Yong $\mathrm{Yu}^{2}{ }^{2}$ Bo $\mathrm{Chen}^{2}$ \\ and Yu-Zhong Zhang ${ }^{1}$
}

Correspondence

Yu-Zhong Zhang

zhangyz@sdu.edu.cn

Yong Yu

yuyong@pric.gov.cn

\author{
${ }^{1}$ The State Key Laboratory of Microbial Technology, Marine Biotechnology Research Center, \\ Shandong University, Jinan 250100, PR China \\ ${ }^{2}$ SOA Key Laboratory for Polar Science, Polar Research Institute of China, Shanghai 200136, \\ PR China
}

\begin{abstract}
A Gram-negative, motile, psychrotolerant, oxidase- and catalase-positive bacterium, designated $\mathrm{BSs} 20135^{\top}$, was isolated from Arctic marine sediment. Cells were straight or slightly curved rods and formed circular, convex and yellowish-brown colonies. Buds and prosthecae could be produced. The strain grew at $4-28{ }^{\circ} \mathrm{C}$ (optimum $25{ }^{\circ} \mathrm{C}$ ) and with $1-5 \%(\mathrm{w} / \mathrm{v}) \mathrm{NaCl}$ (optimum $2 \%$ ) and hydrolysed aesculin and DNA, but did not reduce nitrate to nitrite. Phylogenetic analysis of $16 \mathrm{~S}$ rRNA gene sequences indicated that strain $\mathrm{BSs} 20135^{\top}$ belonged to the genus Glaciecola and shared 93.6-97.7\% sequence similarity with the type strains of known species of the genus Glaciecola. The major cellular fatty acids of strain BSs $20135^{\top}$ were summed feature 3

(comprising $\mathrm{C}_{16: 1} \omega 7 c$ and/or iso- $\mathrm{C}_{15: 0} 2-\mathrm{OH}$ ), $\mathrm{C}_{16: 0}, \mathrm{C}_{17: 1} \omega 8 \mathrm{c}$ and $\mathrm{C}_{18: 1} \omega 7 \mathrm{c}$. The genomic DNA G $+\mathrm{C}$ content was $40.3 \mathrm{~mol} \%$. Based on $16 \mathrm{~S}$ rRNA gene sequence analysis, DNA-DNA hybridization data and phenotypic and chemotaxonomic characterization, strain BSs $20135^{\top}$ represents a novel species, for which the name Glaciecola arctica sp. nov. is proposed. The type strain is BSs $20135^{\top}\left(=\mathrm{CCTCC} A B 209161^{\top}=\operatorname{KACC} 14537^{\top}\right)$.
\end{abstract}

The genus Glaciecola, belonging to the class Gammaproteobacteria, was originally proposed by Bowman et al. (1998) to accommodate two Gram-negative, psychrophilic, aerobic and seawater-requiring species that were isolated from sea-ice cores collected from coastal areas of eastern Antarctica, i.e. Glaciecola punicea (type species) and Glaciecola pallidula. Since then, seven more species of this genus have been isolated from diverse marine habitats: Glaciecola mesophila from marine invertebrates (Romanenko et al., 2003), G. polaris from Arctic seawater (Van Trappen et al., 2004), G. nitratireducens from surface seawater (Baik et al., 2006), G. psychrophila from Arctic seaice (Zhang et al., 2006), G. chathamensis from Pacific Ocean sediment (Matsuyama et al., 2006), G. agarilytica from marine sediment (Yong et al., 2007) and G. lipolytica from coastal surface seawater (Chen et al., 2009). In this study, we report on a novel bacterium, designated BSs $20135^{\mathrm{T}}$, that was isolated from Arctic marine sediment.

Surface sediment samples $(0-5 \mathrm{~cm})$ were collected from the Arctic Ocean $\left(162^{\circ} 31^{\prime} 05^{\prime \prime} \mathrm{W} 77^{\circ} 31^{\prime} 40^{\prime \prime} \mathrm{N}\right)$ at a water

The GenBank/EMBL/DDBJ accession number for the 16S rRNA gene sequence of strain BSs20135 is EU365479.

A supplementary table, references and figure are available with the online version of this paper. depth of $2200 \mathrm{~m}$ during the second Chinese National Arctic Research Expedition cruise of the Chinese icebreaker Xue Long into the Canada Basin in August 2003. Samples were stored in sterilized plastic bags $(250 \mathrm{ml})$ and transported to the laboratory at $4{ }^{\circ} \mathrm{C}$. Bacterial strains were isolated from sediment samples and purified as described previously (Zhang et al., 2010) except that sterilized natural Arctic seawater was used. Strain BSs $20135^{\mathrm{T}}$ was routinely cultivated in TYS broth [containing $0.5 \%$ tryptone (Oxoid), $0.1 \%$ yeast extract (Oxoid), artificial seawater $\left(2.75 \% \mathrm{NaCl}, 0.5 \% \mathrm{MgCl}_{2}, 0.2 \%\right.$ $\mathrm{MgSO}_{4}, 0.05 \% \mathrm{CaCl}_{2}, 0.1 \% \mathrm{KCl}, 0.0001 \% \mathrm{FeSO}_{4}$ and distilled water); Smibert \& Krieg, 1994; pH 7.0] or on TYS agar $\left(1.5 \%\right.$ agar) and was stored at $-80{ }^{\circ} \mathrm{C}$ in TYS broth with $16 \%(\mathrm{v} / \mathrm{v})$ glycerol. G. chathamensis JCM $13645^{\mathrm{T}}$ (from the Japan Collection of Microorganisms, Saitama, Japan), G. mesophila DSM $15026^{\mathrm{T}}$ and G. polaris DSM $16457^{\mathrm{T}}$ (from DSMZ, Braunschweig, Germany) and G. psychrophila $170^{\mathrm{T}}$ (kept in our laboratory) were used as reference strains in some experiments. The reference strains were routinely cultivated on TYS agar or in TYS broth at $25{ }^{\circ} \mathrm{C}\left(12{ }^{\circ} \mathrm{C}\right.$ for G. psychrophila $\left.170^{\mathrm{T}}\right)$.

Genomic DNA extraction and PCR amplification and sequencing of the $16 \mathrm{~S}$ rRNA gene were performed as described previously (Zhang et al., 2010). The obtained 16S 
rRNA gene sequence of strain BSs $20135^{\mathrm{T}}$ was aligned manually with reference sequences retrieved from GenBank using MEGA version 4.0 (Tamura et al., 2007). The phylogenetic tree was generated using MEGA with the neighbour-joining method (Saitou \& Nei, 1987). Evolutionary distances were calculated using the model according to Jukes \& Cantor (1969). The topology of the resultant tree was evaluated by bootstrap analysis with 1000 replications (Felsenstein, 1985). Genomic DNA G+C content was determined by the thermal denaturation temperature $\left(T_{\mathrm{m}}\right)$ method (Marmur \& Doty, 1962) with Escherichia coli K-12 genomic DNA as a control. DNADNA hybridization experiments were carried out using the thermal denaturation and renaturation method (De Ley et al., 1970) as modified by Huß et al. (1983) with a Beckman DU800 spectrophotometer.

Cellular fatty acid analysis was performed using the standard Microbial Identification System (MIDI) at the Institute of Microbiology and Epidemiology, Academy of Military Medical Sciences, Beijing, PR China. The Gram reaction was examined following the non-staining method (Buck, 1982). Motility was examined by light microscopy (CX21; Olympus) using wet mounts. Cell morphology was observed by transmission electron microscopy (JEM100CX II; JEOL) after cells were negatively stained with $2 \%$ phosphotungstic acid for 5 and 10 s. Colony morphology was observed after incubation on TYS agar at $25{ }^{\circ} \mathrm{C}$ for 7-15 days. Growth at $4,10,15,20,25,28,30$ and $37^{\circ} \mathrm{C}$ was measured in TYS broth. Growth with $0,1,2,3,4,5,6,8$ and $10 \%(\mathrm{w} / \mathrm{v}) \mathrm{NaCl}$ was measured in modified TYS broth. Oxidase activity was determined using commercial oxidase test strips (Merck). Catalase activity was detected by bubble production in a $3 \%(\mathrm{v} / \mathrm{v})$ hydrogen peroxide solution. DNase activity was tested using DNase test agar (Oxoid) prepared with artificial seawater. Hydrolysis of casein, starch and Tween 80 was tested on TYS agar supplemented with $1 \%(\mathrm{w} / \mathrm{v})$ skimmed milk, $0.2 \%(\mathrm{w} / \mathrm{v})$ soluble starch or $1 \%$ $(\mathrm{v} / \mathrm{v})$ Tween 80 . Susceptibility to antibiotics was tested using commercial filter paper discs with different antibiotics (Tianhe Micro-organism Reagent Co) on TYS agar. Other enzyme activities and biochemical characteristics were detected using API ZYM, API 20 E, API 20 NE strips (bioMérieux) and GN2 MicroPlates (Biolog) according to the manufacturers' instructions except that cells for inoculation were suspended in artificial seawater. Growth under anaerobic conditions was determined in marine broth 2216 (Difco) for 10 days using an anaerobic chamber (Forma 1029; Thermo Electron).

An almost-complete (1497 nt) 16S rRNA gene sequence of strain BSs $20135^{\mathrm{T}}$ was obtained. Analysis revealed that strain $\mathrm{BSs} 20135^{\mathrm{T}}$ was affiliated with the genus Glaciecola. The isolate showed the highest 16S rRNA gene sequence similarity to G. psychrophila $170^{\mathrm{T}}$ (97.7\%), G. mesophila KMM $241^{\mathrm{T}}(97.4 \%)$ and G. polaris LMG $21857^{\mathrm{T}}(97.1 \%)$; lower 16S rRNA gene sequence similarities (93.6-96.5\%) were observed with the other members of the genus Glaciecola. In the neighbour-joining tree (Fig. 1), strain BSs $20135^{\mathrm{T}}$ and G. psychrophila $170^{\mathrm{T}}$ formed a coherent cluster within the genus Glaciecola, which was supported by a high bootstrap level (99\%). DNA-DNA relatedness between strain BSs $20135^{\mathrm{T}}$ and G. psychrophila $170^{\mathrm{T}}, G$. mesophila DSM $15026^{\mathrm{T}}$ and G. polaris DSM $16457^{\mathrm{T}}$ was $39.3,37.5$ and $28.1 \%$, respectively. These values were below the $70 \%$ cut-off for species discrimination, which indicated that the isolate represented a novel species in the genus Glaciecola (Wayne et al., 1987; Stackebrandt \& Goebel, 1994).

The DNA G+C content of strain BSs $20135^{\mathrm{T}}$ was $40.3 \mathrm{~mol} \%$, which was within the range of $\mathrm{G}+\mathrm{C}$ contents reported for the genus Glaciecola (40-45 mol\%). The major fatty acids of strain BSs $20135^{\mathrm{T}}$ were summed feature 3 (comprising $\mathrm{C}_{16: 1} \omega 7 c$ and/or iso- $\mathrm{C}_{15: 0} 2-\mathrm{OH} ; 40.7 \%$ ), $\mathrm{C}_{16: 0}(24.6 \%), \mathrm{C}_{17: 1} \omega 8 c(10.0 \%)$ and $\mathrm{C}_{18: 1} \omega 7 c(7.5 \%)$, which were similar to those of known members of the genus Glaciecola (Supplementary Table S1, available in IJSEM Online).

Cells of strain BSs $20135^{\mathrm{T}}$ were Gram-negative, straight or slightly curved rods and could produce buds and prosthecae (Supplementary Fig. S1). The phenotypic

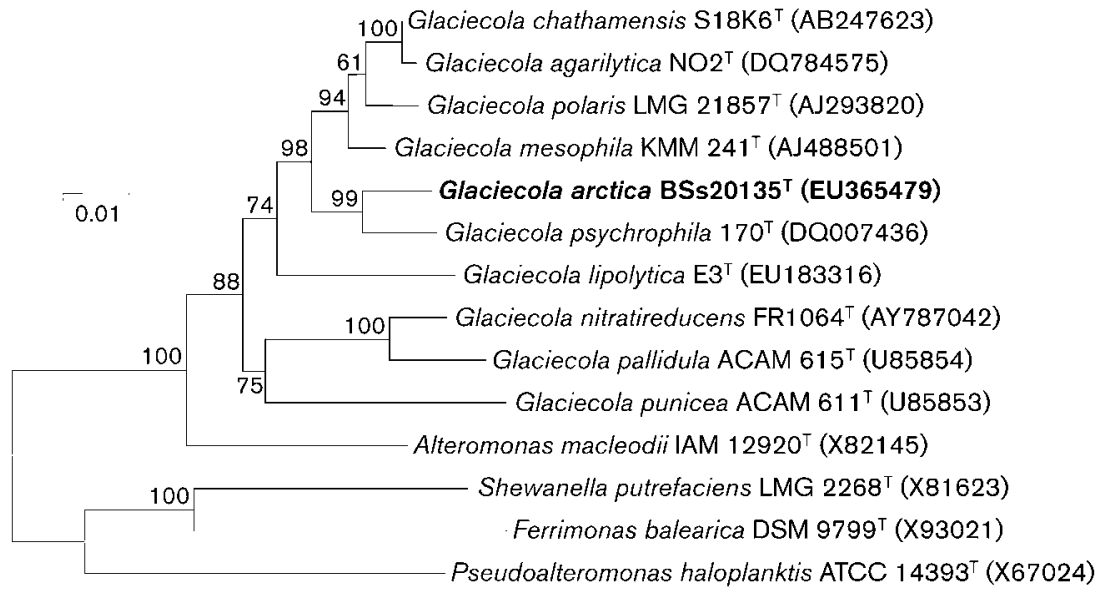

Fig. 1. Neighbour-joining phylogenetic tree based on 16S rRNA gene sequences showing the phylogenetic position of strain BSs20135 among members of the genus Glaciecola and some other related genera. Bootstrap values $(>50 \%)$ based on 1000 replications are shown at branch nodes. Bar, 0.01 substitutions per nucleotide position. 
characteristics of strain BSs $20135^{\mathrm{T}}$ are given in the species description and Table 1. Strain BSs $20135^{\mathrm{T}}$ shared some phenotypic characteristics with other members of the genus Glaciecola, such as the presence of oxidase and catalase, no growth at or above $37^{\circ} \mathrm{C}$, the requirement of sodium ions for growth and the ability to produce buds and prosthecae. However, strain $\mathrm{BSs} 20135^{\mathrm{T}}$ could be phenotypically differentiated from other members of the genus Glaciecola by a combination of phenotypic characteristics, such as range and optimal temperature for growth, growth with $6 \%(\mathrm{w} / \mathrm{v}) \mathrm{NaCl}$, nitrate reduction, hydrolysis of different substrates and carbon-source utilization pattern, as shown in Table 1 .

In total, phylogenetic analysis of $16 \mathrm{~S}$ rRNA gene sequences, phenotypic and chemotaxonomic characteristics and DNA-DNA relatedness indicate that strain BSs $20135^{\mathrm{T}}$ should be assigned to the genus Glaciecola as a representative of a novel species, for which the name Glaciecola arctica sp. nov. is proposed.

\section{Description of Glaciecola arctica sp. nov.}

Glaciecola arctica (arc'ti.ca. L. fem. adj. arctica northern, from the Arctic).

Cells are Gram-negative, straight or slightly curved rods $(0.4-0.8 \times 1.3-4.8 \mu \mathrm{m})$. Motile by a single polar flagellum. Buds and prosthecae can be formed. Colonies on TYS agar are circular, convex and smooth with entire edges. In TYS broth, cell aggregates are yellowish-brown. Oxidase- and catalase-positive. Grows at $4-28{ }^{\circ} \mathrm{C}$ (optimum $25{ }^{\circ} \mathrm{C}$ ) and with $1-5 \%(w / v) ~ \mathrm{NaCl}$ (optimum $2 \% \mathrm{NaCl}$ ); $\mathrm{NaCl}$ is required for growth. Hydrolyses aesculin and DNA, but does not hydrolyse casein, Tween 80 or starch (API 20 NE). Does not reduce nitrate to nitrite (API $20 \mathrm{NE}$ ). Does not produce indole, acetoin (Voges-Proskauer reaction) or $\mathrm{H}_{2} \mathrm{~S}$ (API 20 E). Produces alkaline phosphatase, leucine arylamidase, valine arylamidase, acid phosphatase, naphthol-AS-BI-phosphohydrolase, esterase (C4) (weak), esterase lipase (C8) (weak), cystine arylamidase (weak) and

Table 1. Differential characteristics of strain $\mathrm{BSs} 20135^{\top}$ and members of the genus Glaciecola

Strains: 1, Glaciecola arctica sp. nov. BSs $20135^{\mathrm{T}} ; 2$, G. psychrophila $170^{\mathrm{T}} ; 3$, G. mesophila DSM $15026^{\mathrm{T}} ; 4$, G. polaris DSM $16457^{\mathrm{T}}$ (data for columns 1-4 were taken from this study); 5, G. chathamensis JCM $13645^{\mathrm{T}}$ (Matsuyama et al., 2006); 6, G. agarilytica LMG 23762 ${ }^{\mathrm{T}}$ (Yong et al., 2007); 7, G. lipolytica JCM 15139 ${ }^{\mathrm{T}}$ (Chen et al., 2009); 8, G. nitratireducens FR 1064 ${ }^{\mathrm{T}}$ (Baik et al., 2006); 9, G. pallidula ACAM 615 ${ }^{\mathrm{T}}$ (Bowman et al., 1998); 10, G. punicea ACAM $611^{\mathrm{T}}$ (Bowman et al., 1998). +, Positive; -, negative; ND, no data available.

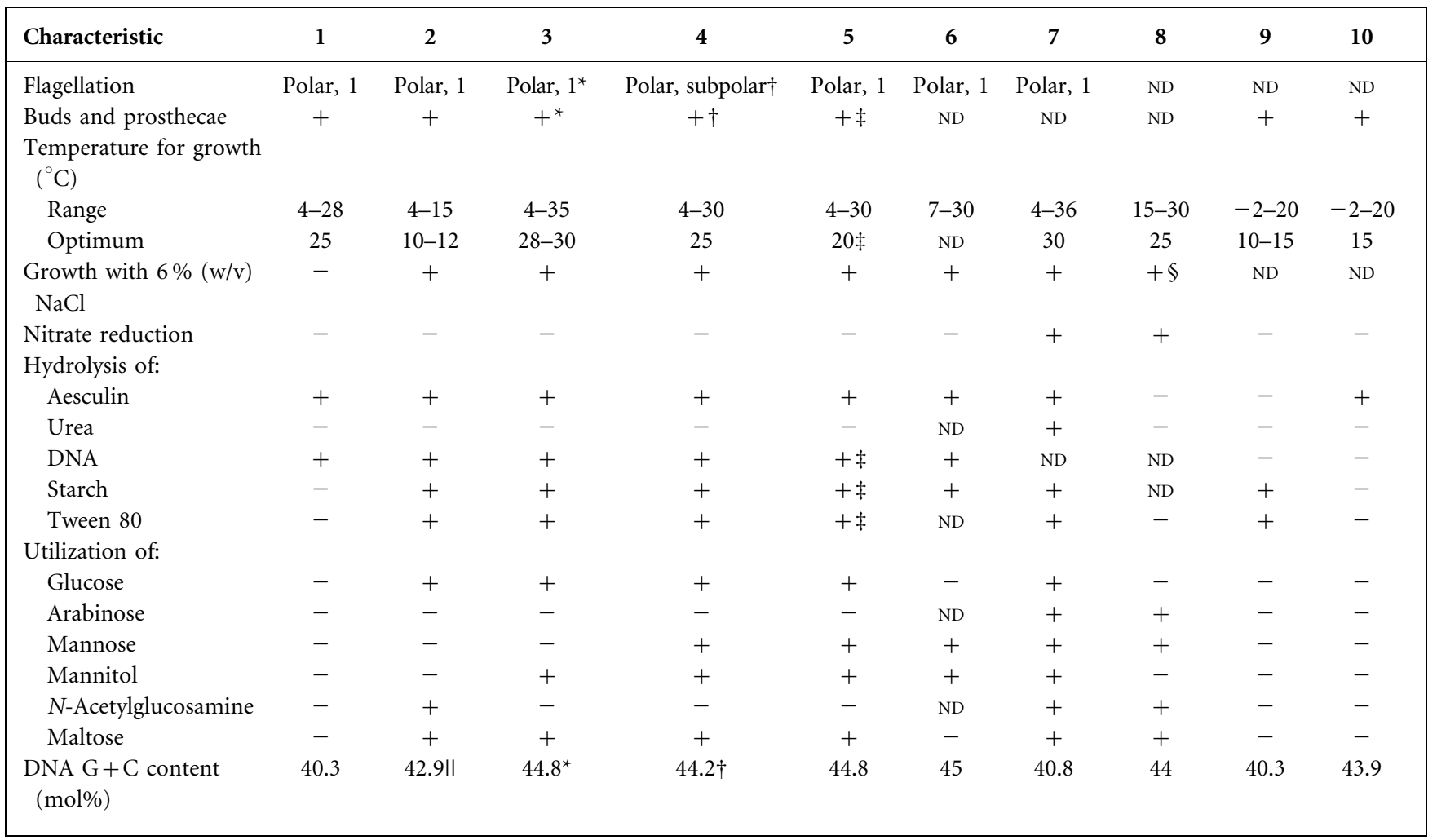

${ }^{*}$ Data from Romanenko et al. (2003).

$\dagger$ Data from Van Trappen et al. (2004).

\$Data from this study.

$\S$ Sea-salt concentration.

IIData from Zhang et al. (2006). 
trypsin (weak), but not lipase (C14), $\alpha$-chymotrypsin, $\alpha$ - or $\beta$-galactosidase, $\beta$-glucuronidase, $\alpha$ - or $\beta$-glucosidase, $N$ acetyl- $\beta$-glucosaminidase, $\alpha$-mannosidase or $\beta$-fucosidase (API ZYM). Positive for acid production from glucose, but negative for arginine dihydrolase, lysine decarboxylase, ornithine decarboxylase, urease, tryptophan deaminase, gelatinase, utilization of citrate and acid production from mannitol, inositol, sorbitol, rhamnose, sucrose, melibiose, amygdalin and arabinose (API 20 E). Does not assimilate glucose, arabinose, mannose, mannitol, $\mathrm{N}$-acetylglucosamine, maltose, gluconate, decanoate, adipic acid, malic acid, citrate or phenylacetic acid (API $20 \mathrm{NE}$ ). No reactions are observed with GN2 MicroPlates after 7 days at $25{ }^{\circ} \mathrm{C}$. Resistant to tetracycline ( $30 \mu \mathrm{g}$ per disc); sensitive to ( $\mu \mathrm{g}$ per disc) gentamicin (10), chloromycetin (30), erythromycin (15), kanamycin (30), streptomycin (10), carbenicillin (100), amikacin (30), polymyxin (30) and vancomycin (30). The major cellular fatty acids are summed feature 3 (comprising $\mathrm{C}_{16: 1} \omega 7 c$ and/or iso- $\mathrm{C}_{15: 0} 2-\mathrm{OH}$ ), $\mathrm{C}_{16: 0}$, $\mathrm{C}_{17: 1} \omega 8 c$ and $\mathrm{C}_{18: 1} \omega 7 c$. The DNA $\mathrm{G}+\mathrm{C}$ content of the type strain is $40.3 \mathrm{~mol} \%$.

The type strain, BSs $20135^{\mathrm{T}} \quad\left(=\mathrm{CCTCC}\right.$ AB $209161^{\mathrm{T}}$ $=$ KACC $14537^{\mathrm{T}}$ ), was isolated from Arctic sediment.

\section{Acknowledgements}

We especially thank Dr Xue-Wei Xu and Dr Fan-Xu Meng from the Second Institute of Oceanography, State Oceanic Administration, for their help with the DNA-DNA hybridization experiments. This study was supported financially by the Hi-Tech Research and Development Program of China (grant 2007AA091903 and 2007AA021306), the National Natural Science Foundation of China (grants 40706001 and 30500001) and the COMRA Program (grant no. DYXM-115-02-2-6).

\section{References}

Baik, K. S., Park, Y.-D., Seong, C. N., Kim, E. M., Bae, K. S. \& Chun, J. (2006). Glaciecola nitratireducens sp. nov., isolated from seawater. Int J Syst Evol Microbiol 56, 2185-2188.

Bowman, J. P., McCammon, S. A., Brown, J. L. \& McMeekin, T. A. (1998). Glaciecola punicea gen. nov., sp. nov. and Glaciecola pallidula gen. nov., sp. nov.: psychrophilic bacteria from Antarctic sea-ice habitats. Int J Syst Bacteriol 48, 1213-1222.

Buck, J. D. (1982). Nonstaining $(\mathrm{KOH})$ method for determination of gram reactions of marine bacteria. Appl Environ Microbiol 44, 992-993.

Chen, L.-P., Xu, H.-Y., Fu, S.-Z., Fan, H.-X., Liu, Y.-H., Liu, S.-J. \& Liu, Z.-P. (2009). Glaciecola lipolytica sp. nov., isolated from seawater near Tianjin city, China. Int J Syst Evol Microbiol 59, 73-76.

De Ley, J., Cattoir, H. \& Reynaerts, A. (1970). The quantitative measurement of DNA hybridization from renaturation rates. Eur $J$ Biochem 12, 133-142.
Felsenstein, J. (1985). Confidence limits on phylogenies: an approach using the bootstrap. Evolution 39, 783-791.

Huß, V. A. R., Festl, H. \& Schleifer, K. H. (1983). Studies on the spectrophotometric determination of DNA hybridization from renaturation rates. Syst Appl Microbiol 4, 184-192.

Jukes, T. H. \& Cantor, C. R. (1969). Evolution of protein molecules. In Mammalian Protein Metabolism, pp. 21-132. Edited by H. N. Munro. New York: Academic Press.

Marmur, J. \& Doty, P. (1962). Determination of the base composition of deoxyribonucleic acid from its thermal denaturation temperature. J Mol Biol 5, 109-118.

Matsuyama, H., Hirabayashi, T., Kasahara, H., Minami, H., Hoshino, T. \& Yumoto, I. (2006). Glaciecola chathamensis sp. nov., a novel marine polysaccharide-producing bacterium. Int J Syst Evol Microbiol 56, 2883-2886.

Romanenko, L. A., Zhukova, N. V., Rohde, M., Lysenko, A. M., Mikhailov, V. V. \& Stackebrandt, E. (2003). Glaciecola mesophila sp. nov., a novel marine agar-digesting bacterium. Int J Syst Evol Microbiol 53, 647-651.

Saitou, N. \& Nei, M. (1987). The neighbor-joining method: a new method for reconstructing phylogenetic trees. Mol Biol Evol 4, 406425.

Smibert, R. M. \& Krieg, N. R. (1994). Phenotypic characterization. In Methods for General and Molecular Bacteriology, pp. 607-654. Edited by P. Gerhardt, R. G. E. Murray, W. A. Wood \& N. R. Krieg. Washington, DC: American Society for Microbiology.

Stackebrandt, E. \& Goebel, B. M. (1994). Taxonomic note: a place for DNA-DNA reassociation and 16S rRNA sequence analysis in the present species definition in bacteriology. Int J Syst Bacteriol 44, 846849.

Tamura, K., Dudley, J., Nei, M. \& Kumar, S. (2007). MEGA4: Molecular Evolutionary Genetics Analysis (MEGA) software version 4.0. Mol Biol Evol 24, 1596-1599.

Van Trappen, S., Tan, T.-L., Yang, J., Mergaert, J. \& Swings, J. (2004). Glaciecola polaris sp. nov., a novel budding and prosthecate bacterium from the Arctic Ocean, and emended description of the genus Glaciecola. Int J Syst Evol Microbiol 54, 1765-1771.

Wayne, L. G., Brenner, D. J., Colwell, R. R., Grimont, P. A. D., Kandler, O., Krichevsky, M. I., Moore, L. H., Moore, W. E. C., Murray, R. G. E. \& other authors (1987). International Committee on Systematic Bacteriology. Report of the ad hoc committee on reconciliation of approaches to bacterial systematics. Int J Syst Bacteriol 37, 463-464.

Yong, J.-J., Park, S.-J., Kim, H.-J. \& Rhee, S.-K. (2007). Glaciecola agarilytica sp. nov., an agar-digesting marine bacterium from the East Sea, Korea. Int J Syst Evol Microbiol 57, 951-953.

Zhang, D.-C., Yu, Y., Chen, B., Wang, H.-X., Liu, H.-C., Dong, X.-Z. \& Zhou, P.-J. (2006). Glaciecola psychrophila sp. nov., a novel psychrophilic bacterium isolated from the Arctic. Int J Syst Evol Microbiol 56, 2867-2869.

Zhang, X.-Y., Zhang, Y.-J., Yu, Y., Li, H.-J., Gao, Z.-M., Chen, X.-L., Chen, B. \& Zhang, Y.-Z. (2010). Neptunomonas antarctica sp. nov., isolated from marine sediment. Int J Syst Evol Microbiol 60, 19581961. 